\title{
DYNAMICAL CHARACTERIZATION OF TYPICAL MEXICAN COLONIAL CHURCHES
}

\author{
Fernando Peña, Julio Manzano and Laura Robles \\ Instituto de Ingeniería, Universidad Nacional Autónoma de México \\ Edificio 2 - 401, Circuito Escolar, Ciudad Universitaria, Mexico city, Mexico \\ e-mail: fpem@pumas.iingen.unam.mx,JManzanoO@ii.unam.mx, MRoblesA@ii.unam.mx
}

Keywords: Dynamical Characterization, Colonial Churches, Historical Masonry, Seismic Vulnerability, Seismic Safety.

\begin{abstract}
The dynamical characterization of ancient masonry churches built in the colonial era in Mexico by means of a case study is presented. The seismic assessment of old masonry churches is not an easy task, mainly due to the fact that the churches are large structures with complex geometries and built with materials with highly nonlinear behavior. These constructions vary in architectural styles, but mostly follow some basic typologies. The simplest one is the small parochial church which can be found in every village and town in Mexico.

The dynamical characterization was performed by means of a study case of a typical church of the center of Mexico. The aim of the characterization is to develop a methodology to study the seismic vulnerability of this type of constructions. The study is based on complementary analysis approach. Thus, three steps were performed: a)preliminary studies, which must include historical information, materials and geometry description and survey of the structure, monitoring, non-destructive tests, etc; b) calibration and validation of numerical models, based on the results obtained from the previous step; and c) the dynamical characterization. This approach allows to overcome the complexity of the study of the seismic behavior of ancient masonry structures; by combining the results of different type of models and analysis.

The paper is based on a case study but also provides a very relevant discussion on an issue that has received insufficient attention: the seismic analysis of masonry structures without a box behavior. From the results obtained, it was identified that roof system cannot be considered as rigid diaphragm. The dynamical characterization shows that the belfry and the roof (dome and vaults) are the most critical elements. The church is very rigid, since the lateral wall drifts are so low. Thus out-of-plane and shear behavior in walls are not critical behaviors.
\end{abstract}




\section{INTRODUCTION}

The dynamical characterization of structures is in general a useful tool for the evaluation of seismic safety. The churches built in the colonial era in Mexico vary in size and architectural styles. However, churches of a particular zone follow some basic typologies (both architectural and structural), which depend mainly on the seismic zone where they were built $[1,2]$. Thus, by case studies is possible to extrapolate the results to other similar churches.

The dynamical characterization should be based on theoretical (structural analysis) and experimental bases (NDT). But, in the first place, it must respect the integrity and the artistic and architectural values of the building. In this way, the methodology used must follow the ISCARSAH principles [3, 4]. Therefore, a specific methodology for historic buildings in each country must be developed. Thus, the study of particular cases will allow the development of a methodology for the Mexican case.

The aim of the paper is the dynamical characterization of typical colonial churches, through a case study. The study was limited only to the study of the Saint Bartholomew the Apostle church. This church was chosen for its historical and architectural significance within the area of study.

The methodology followed is based on a stepped strategy named complementary analyses approach [5]. This strategy helps to overcome the difficulties inherent to the analysis of historic structures, through a series of levels or steps:

- Step 1. Preliminary studies. At this step, the preliminary studies of the selected temple was performed. The information collected must include: an historical study and the geometrical, architectural and structural surveys.

- Step 2. Studies for the calibration and validation of the structural models. An ambient vibration test was performed in order to obtained the dynamical characteristics of the temple. It is necessary to have a preliminary numerical model in order to design and perform correctly this test. With the numerical model, it is possible to identify critical areas of the structure, as well as to define the correct position of the equipment used in the experimental tests. Also, at this step was calibrated and validated the numerical models with the results of the ambient vibration test.

- Step 3. Dynamical characterization. With the numerical models calibrated and validated, the dynamical characterization of the temple was carried out. This includes the identification of the mechanical characteristics of the materials and the seismic behavior. As well as the identification of critical elements as appendices or weak elements.

\section{STEP 1. PRELIMINARY STUDIES}

In this step, all information available for further studies is collected. Which must include, among others: historical information, materials and geometry description, architectural and structural survey, preliminary studies, etc. Historical information is very important, because it allows to understand the structural behavior of the building along the time. It is also necessary to have a good description of the temple; since in general, geometry of historic buildings is quite complex. So often there is not a clear difference between structural and architectural elements.

The architectural and structural survey of the temple is one of the most important information that must be collected. With this information, it is possible to carry out preliminary numerical models. These models were developed based on the geometric information obtained from surveys and nominal properties of the materials found in the literature. 


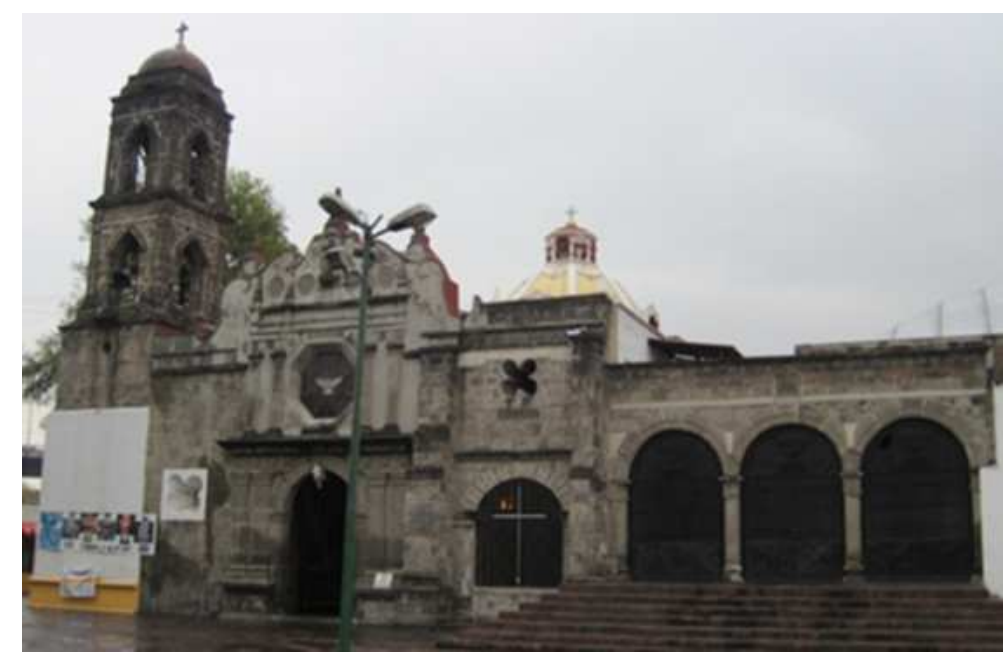

Figure 1: Actual view of the church

\subsection{Historical study}

The St. Bartholomew the Apostle church is located at the north of Mexico city. In the colonial era, it was common to establish Indian towns around religious centers, in order to make easier the evangelization. In this way, the village of St. Barth was founded, which soon became an important town. The date of construction of the church is not known, but there are some administrative records from 1649 [6]. This means that its construction should be between the late $16^{\text {th }}$ and early $17^{\text {th }}$ century. The church was founded by the Franciscan order and has a modest and simple architecture without great decorations, according to the canons of the Franciscan Order [7].

The church has been struck by several seismic events of medium and high intensity. Due to this, the temple has been repaired and modified along the time. Unfortunately, there are not detailed historical records about these changes. However, by means of a photo record of the $20^{\text {th }}$ century [8] was possible to identify some important changes.

For example, Figures 1 and 2a show the façade actually and at the middle of the 40's. Comparing both figures is possible to observe significant changes in the façade. The right side window was expanded. The frontispiece is different, although it tried to preserve the original style. The buttress on the right side of the main door is new. Figure $2 b$ seems to be from the 50's of the past century. Compared with Figure 2a, it is possible to see that the frontispiece is the same but without the pinnacles. The right side door and the buttress of the façade were already built but with a different architectural style.

It is reported that in the second half of 1960, the temple had several damages. The main façade was on risk to collapse. Several structural and architectural elements partially collapsed. The frontispiece collapsed. Due to these collapses, the temple was reinforced and restructured. Vaults were rebuilt with concrete and reinforced with concrete ribs. Several walls were reinforced, the belfry and the chapel and chorus slabs were rebuilt with concrete. The frontispiece and the portal were totally reconstructed with reinforced concrete elements.

\subsection{Architectural and structural survey}

The church has a Latin-cross floor plan, oriented in direction East-West. The main nave has a length of $31.5 \mathrm{~m}$ and a width of $7 \mathrm{~m}$. While the transverse nave is $14 \times 8 \mathrm{~m}^{2}$. In the first 
a)

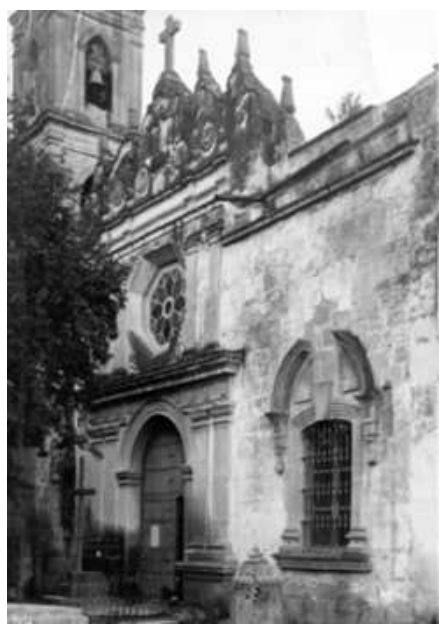

b)

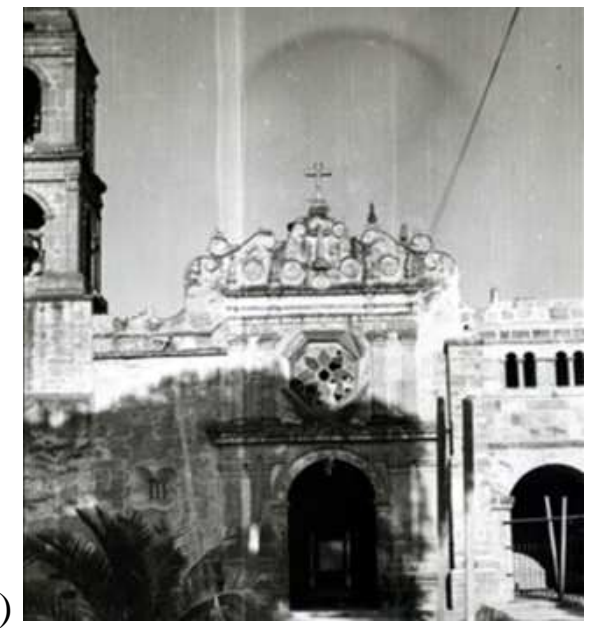

Figure 2: View of the Façade [8] in the past century, decade of: a) 40's; b) 50's

bay there is an intermediate floor for the chorus. The roof is constituted by a barrel vaulting system with a thickness of $20 \mathrm{~cm}$. A hemispherical dome is placed over the transept bay and it is supported by the drum. The average height of the walls is $6 \mathrm{~m}$, while the height of the vaults, from the ground, is $8.75 \mathrm{~m}$. The total height of dome is $13.95 \mathrm{~m}$. The church has a bell tower of $13.75 \mathrm{~m}$ high. In plan, the tower has a rectangular section of $3.5 \times 4.2 \mathrm{~m}^{2}$. The thick of the walls varies from 0.85 to $1 \mathrm{~m}$. Trapezoidal buttresses are placed along the longitudinal walls of the nave and in the apse.

The main material of construction is a heterogeneous masonry constituted by stones agglutinated by lime-sand mortar. Frequently, broken clay bricks or lightweight volcanic stones were added to the masonry. This heterogeneous masonry constitutes a kind of concrete whose composition varies according to the structural element; it is lighter than normal stone masonry, and has a tensile strength bigger than brick masonry, due mainly to the absence of weak planes constituted by the mortar layers. Walls are made by stone masonry, while vaults and the dome were rebuilt with concrete.

\subsection{Numerical model}

Based on the information collected, a finite element model was performed (see Fig. 3). Rectangular solid elements of eight nodes were used. The model has 22,509 elements, 96,066 degrees of freedom and 33,650 nodes.

Three types of materials were considered. Walls, columns, buttresses, tower base and arcs are of irregular stone masonry. The belfry was considered of masonry, but different from the walls. Since it presents some concrete and steel reinforcements. Finally, the vaults, the frontispiece, ribs and dome were considered of reinforced concrete. Table 1 shows the mechanical properties used in the model, which were obtained from the literature [9].

Table 2 shows the frequencies and percentages of modal mass for the first five modes. The structure is very rigid, as the first frequency is $3.66 \mathrm{~Hz}$. The first two modes correspond to the vibration modes of the tower, which is the most flexible part of the church (Fig. 4a). The third mode is the first mode in the transverse direction with a frequency of $5.05 \mathrm{~Hz}$ (Fig. 4b). The fourth and sixth modes correspond to torsional mode of the tower, while the fifth mode is the first mode in longitudinal direction. It should be noted that all modes have a torsional component, and there is no one mode with a pure form. 


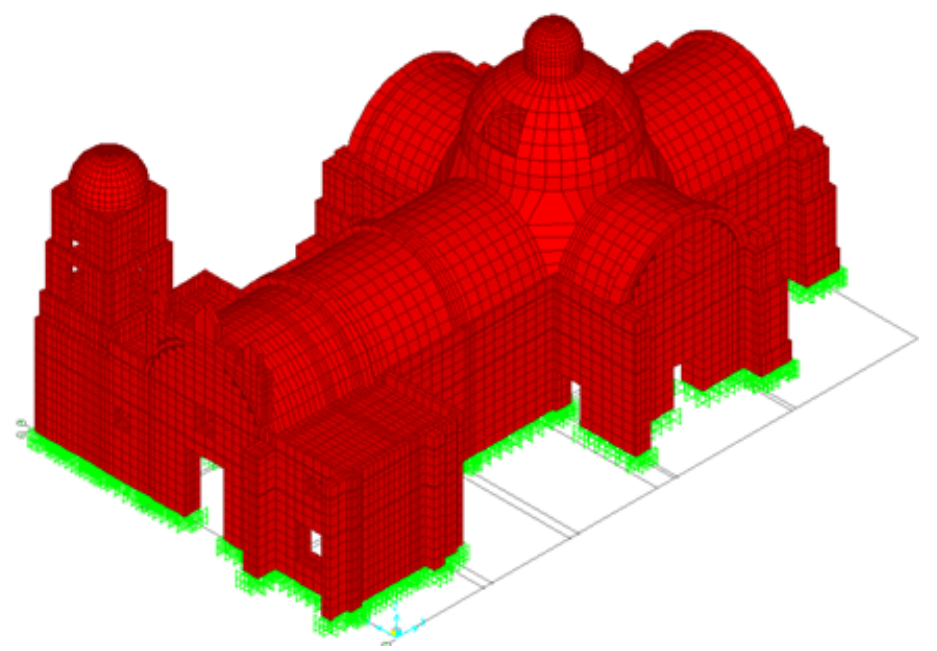

Figure 3: Finite element model of the church

\begin{tabular}{ccccc}
\hline Material & $\begin{array}{c}\text { Compressive } \\
\text { strength }(\mathrm{MPa})\end{array}$ & $\begin{array}{c}\text { Tensile } \\
\text { strength }(\mathrm{MPa})\end{array}$ & $\begin{array}{c}\text { Elastic } \\
\text { modulus }(\mathrm{MPa})\end{array}$ & $\begin{array}{c}\text { Density } \\
\left(\mathrm{kg} / \mathrm{m}^{3}\right)\end{array}$ \\
\hline Wall masonry & 1.5 & 0.12 & 0.60 & 1600 \\
Belfry masonry & 3.0 & 0.24 & 0.25 & 1800 \\
Concrete & 20 & 2.10 & 21.7 & 2400 \\
\hline
\end{tabular}

Table 1: Mechanical properties of the materials [9].

\section{STUDIES FOR THE MODEL CALIBRATION AND VALIDATION}

The aim of the ambient vibration tests is to define the dynamic properties of the church, which include vibration frequencies, mode shapes and damping coefficients. These tests may also be used to assess the degree of connection between the various structural elements of the church. With the results of the test, the numerical models were calibrated. In this way, the mechanical properties of the materials were obtained by calibrating the frequencies and mode shapes of the analytical model with the ambient vibration test.

\subsection{Ambient vibration test}

Based on the results of the finite element model and field survey, the points where the accelerometers should be placed for ambient vibration test were defined. Figure 5 shows schematically the points selected for the installation of the accelerometers. The signals obtained from the tests were processed and interpreted by using an spectral analysis program. For each test, the average power spectra and the corresponding spectral ratios, phase angles and coherence between signal pairs were obtained. For these analyses, each record was processed in sections of $40.96 \mathrm{~s}$, considering a $50 \%$ of overlap between two consecutive segments and a Hanning window weighting type. The analysis of the spectra allowed to obtain several frequencies. Table 3 shows the significant frequencies of the tower, while Tables 4 to 6 shows the significant frequencies of the body of the church. 


\begin{tabular}{ccccc}
\hline Mode & $\begin{array}{c}\text { Frequency } \\
(\mathrm{Hz})\end{array}$ & $\begin{array}{c}\text { Percentage } \\
\text { Longitudinal }\end{array}$ & $\begin{array}{c}\text { of modal } \\
\text { Transverse }\end{array}$ & $\begin{array}{c}\text { mass }(\%) \\
\text { Vertical }\end{array}$ \\
\hline 1 & 3.66 & 2.2 & 1.9 & 0.0 \\
2 & 3.71 & 1.3 & 3.7 & 0.0 \\
3 & 5.05 & 0.1 & 55 & 0.0 \\
4 & 6.41 & 1.8 & 5.7 & 0.0 \\
5 & 6.66 & 62 & 0.0 & 0.0 \\
6 & 7.05 & 0.8 & 2.5 & 0.1 \\
7 & 7.17 & 0.2 & 1.0 & 0.0 \\
8 & 7.27 & 4.8 & 0.1 & 0.0 \\
9 & 8.07 & 0.0 & 0.6 & 0.5 \\
10 & 8.46 & 1.1 & 0.8 & 0.7 \\
\hline
\end{tabular}

Table 2: Dynamical properties.

a)

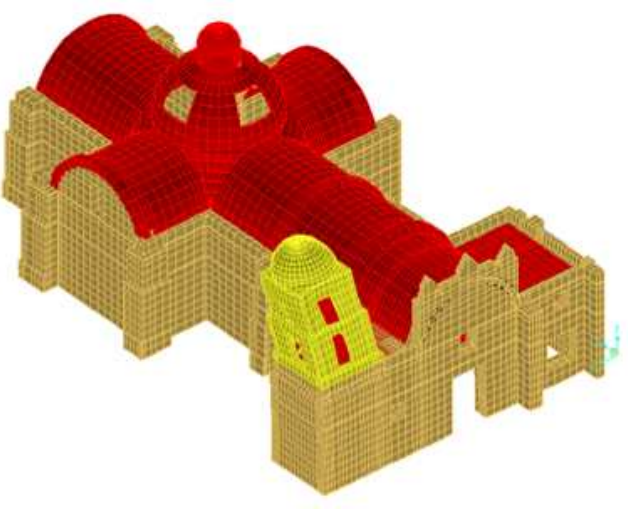

b)

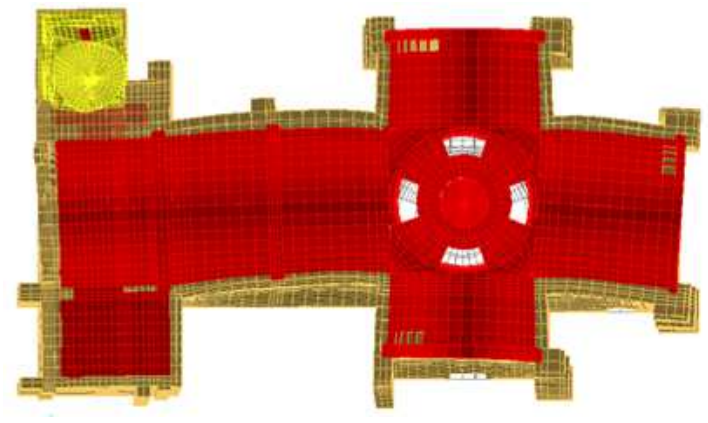

Figure 4: Shape modes: a) first mode; b) third mode

\subsection{Calibration of the numerical model}

The numerical model performed in the previous step considered the properties of the materials found in the literature. In order to have a more reliability model, it was calibrated with the ambient vibration tests. In this particular case, the mechanical properties of the materials were the variables to be calibrated. Thus, four variables were calibrated. Three elasticity modules corresponding to each materials (Table 1). The last variable was the mass density of the masonry of the belfry, since it has a concrete reinforcement. Table 7 shows the base values, limited values and the optimized values. Obviously, the base values correspond to the values used in the preliminary model (Table 1 ).

The variables were optimized by using five frequencies. The first two corresponding to the tower and the frequency corresponding to the first mode in transverse, longitudinal and vertical

\begin{tabular}{cccc}
\hline Mode & Longitudinal & Transverse & Vertical \\
\hline 1 & 3.15 & 3.47 & $7.9-8.0$ \\
2 & $7.7-7.9$ & $8.5-8.8$ & - \\
\hline
\end{tabular}

Table 3: Measured frequencies of the tower $(\mathrm{Hz})$. 

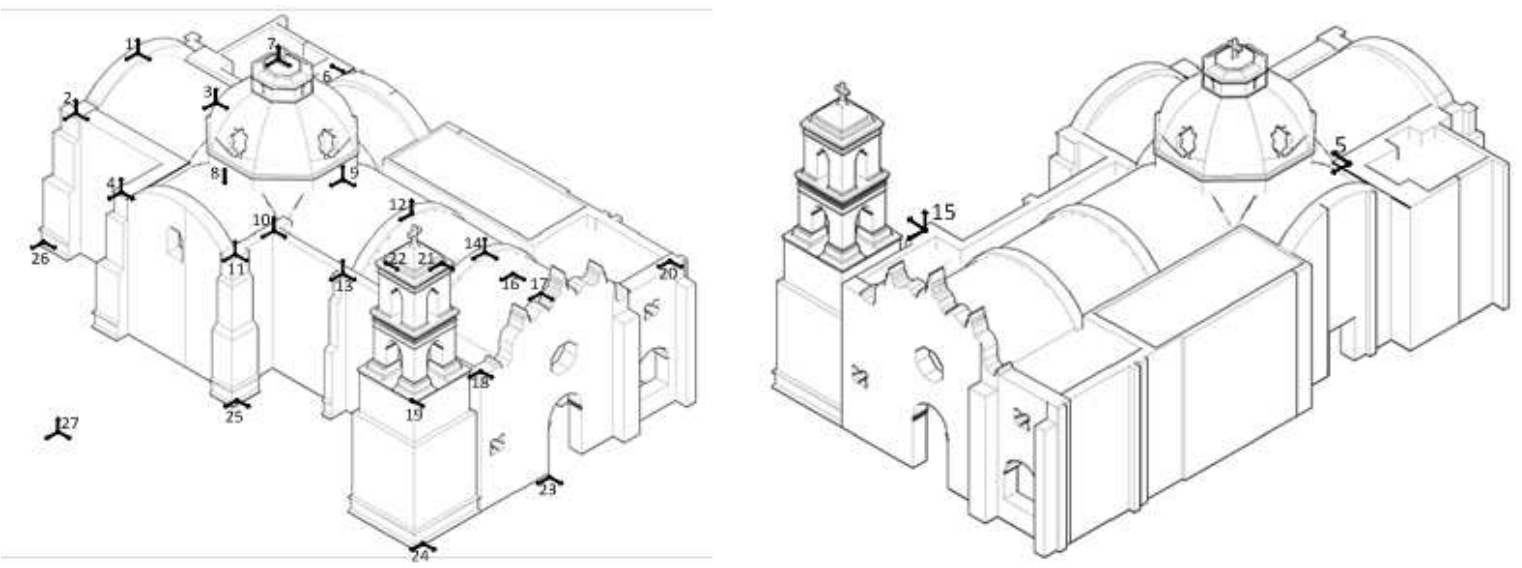

Figure 5: Localization of the measurement points

\begin{tabular}{cccc}
\hline Mode & Nave & Façade & Cupola \\
\hline 1 & $5.6-6.3$ & - & - \\
2 & $8.0-10.3$ & - & $8.2-8.7$ \\
3 & $12.0-15.0$ & $13.5-15.5$ & - \\
\hline
\end{tabular}

Table 4: Measured frequencies of the church, longitudinal direction $(\mathrm{Hz})$.

direction. Table 8 compares the calculated frequencies with the calibrated numerical model with the values measured in the ambient vibration tests. It is noted that errors are acceptable, which are below $10 \%$.

\section{DYNAMIC CHARACTERIZATION}

\subsection{Own weight analysis}

The total weight of the structure is equal to $15,175 \mathrm{kN}$, being the average axial stress in the foundation equal to $0.13 \mathrm{MPa}$. Figure 6a shows the map of vertical axial stresses due to its own weight, while Figure $6 \mathrm{~b}$ shows the deformed model.

\subsection{Modal description}

Table 9 shows the dynamical properties of the calibrated model. It is noted that the mode shapes are virtually the same of the original model, only mode 5 was exchanged with mode 6 .

\begin{tabular}{ccccc}
\hline Mode & Apse & Nave & Cupola & Façade \\
\hline 1 & - & 3.47 & - & - \\
2 & - & $4.3-4.8$ & $4.5-4.8$ & - \\
3 & $5.7-7.3$ & $5.7-7.3$ & $5.7-7.3$ & - \\
4 & $6.1-7.1$ & $6.1-7.1$ & - & - \\
5 & - & - & $8.3-9.3$ & - \\
6 & - & - & $10.9-12.7$ & $14.8-15.7$ \\
\hline
\end{tabular}

Table 5: Measured frequencies of the church, transversal direction $(\mathrm{Hz})$. 


\begin{tabular}{ccc}
\hline Mode & Nave vaults & Cupola \\
\hline 1 & $8.1-8.2$ & - \\
2 & - & $18.0-19.0$ \\
\hline
\end{tabular}

Table 6: Measured frequencies of the church, vertical direction $(\mathrm{Hz})$.

\begin{tabular}{cccccc}
\hline Material & Variable & Base & Up Limit & Down Limit & Optimized \\
\hline Masonry & Elasticity modulus $(\mathrm{GPa})$ & 0.60 & 1.00 & 0.40 & 0.40 \\
Belfry masonry & Elasticity modulus $(\mathrm{GPa})$ & 0.25 & 9.81 & 0.20 & 0.25 \\
Belfry masonry & Mass density $\left(\mathrm{t} / \mathrm{m}^{3}\right)$ & 1.80 & 2.20 & 1.60 & 1.60 \\
Concrete & Elasticity modulus $(\mathrm{GPa})$ & 21.72 & 25.70 & 16.82 & 16.82 \\
\hline
\end{tabular}

Table 7: Values used in the optimization of the variables.

This means that the mode 6 is now the first longitudinal mode, while the mode 5 is a torsional mode of the tower. Likewise, it is observed that the vault can not be considered as an infinitely rigid diaphragm. Since the motion of the plant is not uniform as it can be observed in Figure 7.

\subsection{Modal spectral analysis}

A modal spectral analysis was performed considering the design spectrum proposed by the Mexican building code [10]. The church was founded in rock soil, zone I in accordance with the building code. As the structure is considered as type A (historical structure), the stresses must be multiplied by the factor 1.5. Thus, the spectrum will have a maximum ground acceleration equal to $0.6 \mathrm{~m} / \mathrm{s}^{2}$, while the acceleration of the plateau is equal to $2.4 \mathrm{~m} / \mathrm{s}^{2}$. Since the beginning of the plateau starts in the period equal to $0.2 \mathrm{~s}$, only the first two modes (corresponding to the vibration of the tower) fall in the plateau, whereas the other modes lie in the ascending branch. The seismic factor $Q$ is equal to one, since the masonry is considered as non ductile material. This means that the design spectrum was not reduced.

Figures 8 shows the deformed shape with the map of vertical axial stresses, when the earthquake is applied in the transverse and longitudinal direction respectively. It is noted that the analyses consider the combination of the earthquake in the two directions ( $100 \%$ for one direction plus 30\% in the other). It is observed that regardless of the direction of the earthquake, the deformed shape obtained is similar in both cases. The tower has a torsional behavior, which is concentrated in the upper body of the belfry. Likewise, the dome has a slight vertical movement, which produce a stress concentration at the base of the drum.

The vertical axial stresses are also concentrated in the pillars of the belfry and at the base of

\begin{tabular}{ccccc}
\hline Mode & Direction & Calculated frequency & Measured frequency & Error $(\%)$ \\
\hline 1 & $1^{\text {st }}$ Tower & 3.17 & 3.15 & 0.56 \\
2 & $2^{\text {nd }}$ Tower & 3.21 & 3.47 & 8.23 \\
3 & $1^{\text {st }}$ Transversal & 5.02 & 4.55 & 9.39 \\
6 & $1^{\text {st }}$ Longitudinal & 6.62 & 5.95 & 10.18 \\
9 & $1^{\text {st }}$ Vertical & 7.81 & 8.15 & 4.31 \\
\hline
\end{tabular}

Table 8: Frequencies used in the calibration $(\mathrm{Hz})$. 
a)

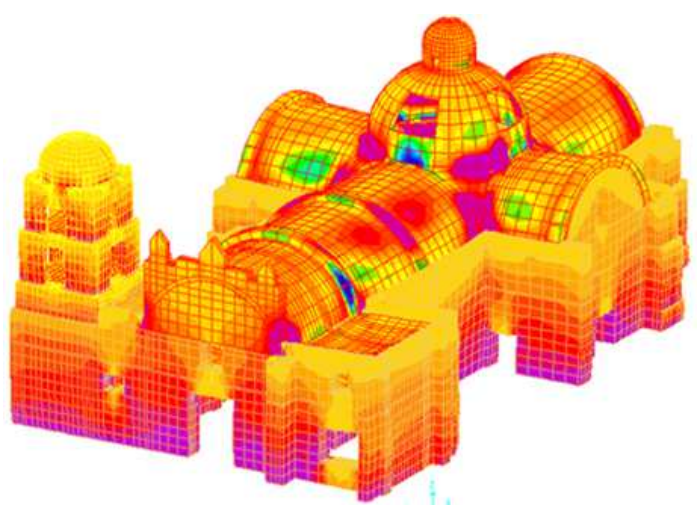

b)

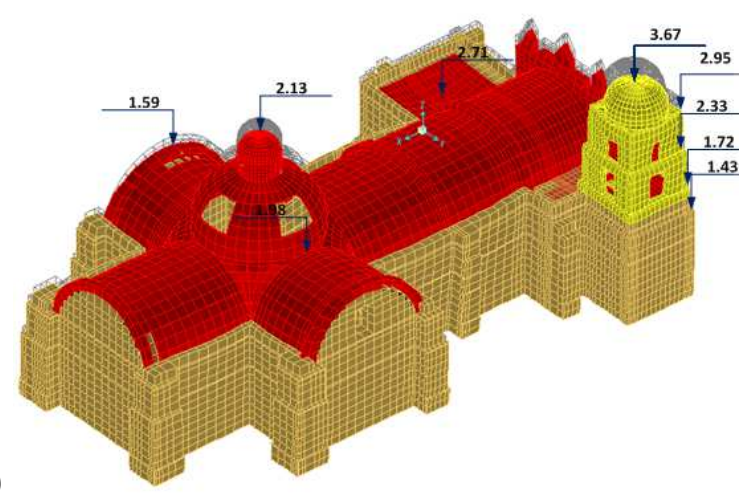

Figure 6: Own weight analysis: a) map of vertical axial stresses; b) deformed shape (displacements in $\mathrm{mm}$ )

\begin{tabular}{ccccc}
\hline Mode & $\begin{array}{c}\text { Frequency } \\
(\mathrm{Hz})\end{array}$ & $\begin{array}{c}\text { Percentage } \\
\text { Longitudinal }\end{array}$ & $\begin{array}{c}\text { of modal } \\
\text { Transverse }\end{array}$ & $\begin{array}{c}\text { mass }(\%) \\
\text { Vertical }\end{array}$ \\
\hline 1 & 3.17 & 2.2 & 1.7 & 0.0 \\
2 & 3.21 & 1.3 & 3.9 & 0.0 \\
3 & 5.02 & 0.0 & 77.8 & 0.3 \\
4 & 6.35 & 0.1 & 6.2 & 0.0 \\
5 & 6.42 & 10.2 & 1.0 & 0.0 \\
6 & 6.62 & 78.5 & 0.1 & 0.0 \\
7 & 7.13 & 0.0 & 4.5 & 2.0 \\
8 & 7.41 & 4.7 & 0.2 & 3.9 \\
9 & 7.81 & 0.1 & 0.3 & 29.5 \\
10 & 8.51 & 0.8 & 2.4 & 32.8 \\
\hline
\end{tabular}

Table 9: Dynamical properties of the calibrated model.

walls and buttresses. A slight vertical stress concentration can be observed in the base of the ribs, which indicates that they are working due to vertical vibration of the vaults. Furthermore, the shear is concentrated in the body of the pillars of the belfry, in the drum and the ribs. It is interesting that the walls do not show important shear stresses. This is because the church has virtually no lateral or longitudinal distortions. Since the motion is concentrated in the tower and roof (dome and vaults). These results show a seismic behavior similar to those found in historical records: the critical elements of this church are the bell tower and the roof.

\section{CONCLUSIONS}

- The dynamical characterization of colonial Mexican churches was performed by means of a case study.

- Ambient vibration test was performed in order to calibrate and validate a finite element model of the church.

- This study follows a stepped strategy in order to overcome the difficulties in the study of historical structures.

- The roof system cannot be considered as rigid diaphragm. 
a)

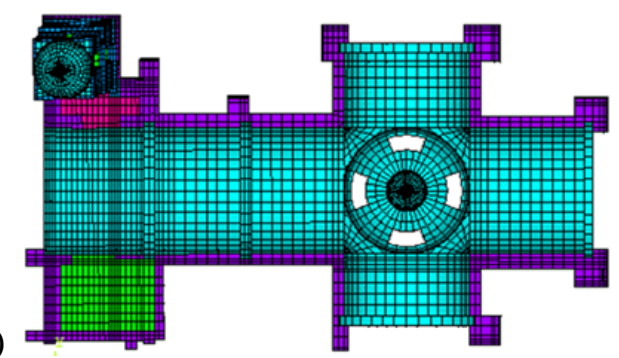

c)

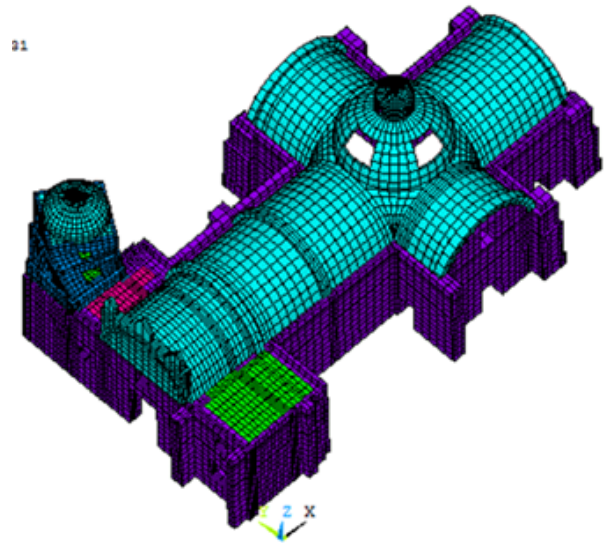

b)

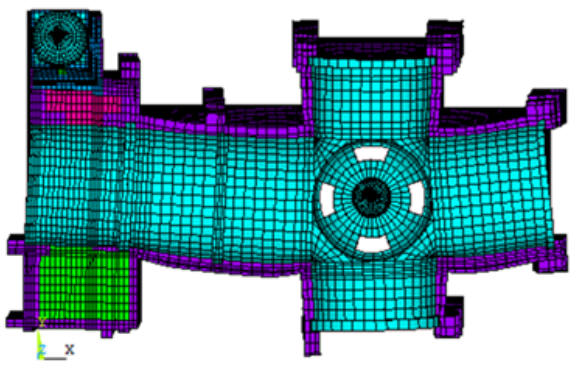

d)

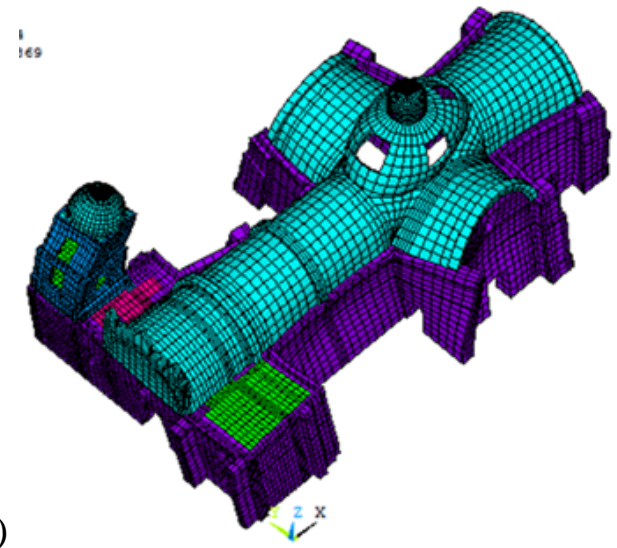

Figure 7: Shape modes: a) first mode; b) third mode; c) fifth mode; d) eight mode

- The dynamical characterization shows that the belfry and the roof (dome and vaults) are the most critical elements.

- The church is very rigid, since the lateral wall drifts are so low. Thus out-of-plane and shear behavior in walls are not a critical behaviors.

\section{ACKNOWLEDGMENTS}

The financial support of the Instituto de Ingeniería, UNAM, by means of the project 1651 Dynamical characterization of colonial churches is acknowledge.

a)

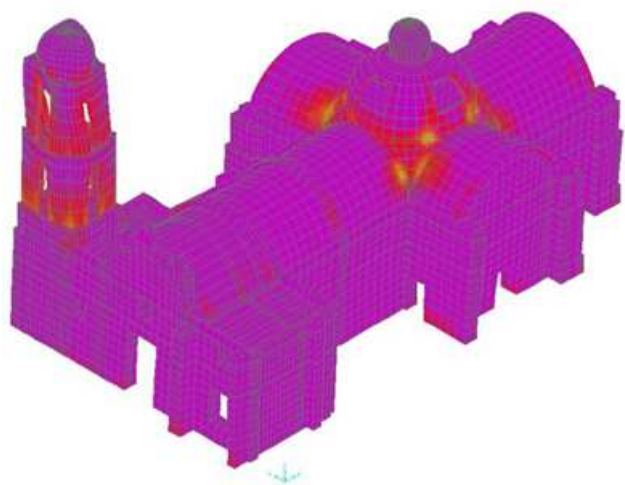

b)

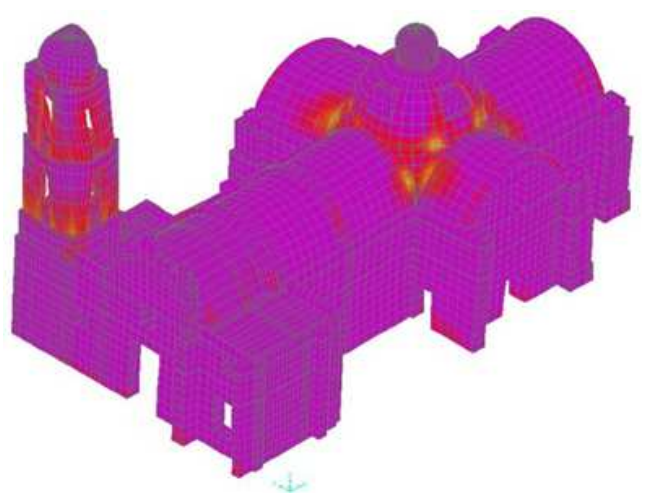

Figure 8: Deformed shape and map of vertical axial stresses: a) 100\% in lateral direction plus $30 \%$ in the longitudinal; b) $30 \%$ in lateral direction plus $100 \%$ in the longitudinal 


\section{REFERENCES}

[1] R. Meli, F. Peña, On elastic models for evaluation of the seismic vulnerability of masonry churches. Lourenço, Roca and Modena eds. Proceeding of Structural Analysis of Historical Constructions (SAHC2004), Padova, Italia, 1121-1131, 2004.

[2] F. Peña, J.M. Meza, Seismic assessment of bell towers of Mexican colonial churches. Lourenço, Roca and Modena eds. Proceeding of Structural Analysis of Historical Constructions (SAHC2010), China, 585-590, 2010.

[3] ICOMOS, International Charter for the Conservation and Restoration of Monuments and Sites (The Venice Charter). ICOMOS, 1964. Available at http://www.icomos.org

[4] ICOMOS, Principles for the Analysis, Conservation and Structural Restoration of Architectural Heritage. ICOMOS, 2003. Available at http://www.icomos.org

[5] F. Peña, P.B. Lourenço, N. Mendes, D.V. Oliveira, Numerical models for the seismic assessment of an old masonry tower. Engineering Structures, 32, 1466-1478, 2010.

[6] R. Lopez, L. Cordoba, Parroquia de San Bartolomé Apóstol. El corazón de Naucalpan. Arquidiócesis de Tlanlneplantla, Mexico, 2011.

[7] C. Astorga, J.L. Rodriguez, Historia de la Arquitectura en México:época virreinal. Editorial UNAM, Mexico, 2009.

[8] INAH, Fototeca Constantino Reyes-Valerio. Coordinación Nacional de Monumentos Históricos, CONACULTA, INAH, Mexico, 2012.

[9] R. Meli, Ingeniería estructural de los edificios históricos. Fundación ICA, Mexico, 1998.

[10] NTC, Normas Técnicas Complementarias para Diseño por Sismo. Reglamento de Construcciones para el Distrito Federal, Mexico, 2004. 